\title{
A CORRELATIONAL STUDY BETWEEN STUDENT'S ENGLISH INTEREST, VOCABULARY MASTERY, AND STUDENT'S ACHIEVEMENT
}

\author{
Sulaiman \\ IAIN Pontianak \\ sulaiman@iainptk.ac.id
}

\begin{abstract}
The study is aimed to reveal the correlation between student's English interest, vocabulary mastery toward student's English achievement of the second semester Students of Islamic Education Department of Teacher Training and Education Faculty of IAIN Pontianak in the academic year of 2017/2018. This study used a test, a questionnaire, and a documentation to collect the data. The population of the study is all of the second semester students while the sample is 50 students taken by cluster random sampling technique. The techniques used to analyze the data are simple and multiple correlation and regression by using SPSS 23 . The results of the study show that there is a positive correlation between student's English interest, and vocabulary mastery toward student's English achievement. The positive correlation indicates that English interest, and vocabulary mastery line together with student's English achievement.
\end{abstract}

keywords: correlation, english interest, vocabulary mastery english achievement

\begin{abstract}
ABSTRAK
Penelitian ini bertujuan untuk mencari korelasi antara penguasaan kosakata dan minat siswa terhadap Bahasa Inggris dengan prestasi Bahasa Inggris mahasiswa semester dua jurusan Pendidikan Agama Islam Fakultas Tarbiyah dan Ilmu Pendidikan IAIN Pontianak tahun ajaran 2017/2018; baik secara tunggal maupun bersamaan. Penelitian ini menggunakan tes, angket, dan dokumentasi sebagai alat untuk mengumpulkan data. Populasi dari penelitian ini adalah seluruh siswa kelas dua sementara sampelnya berjumlah 50 siswa yang diambil dengan teknik sampling acak kelompok. Teknik yang digunakan untuk menganalisis data adalah regresi tunggal dan ganda serta korelasi tunggal dan ganda dengan menggunakan SPSS 23. Hasil penelitian menunjukkan bahwa terdapat korelasi positif antara penguasaan kosakata dan minat siswa terhadap Bahasa Inggris dengan prestasi Bahasa Inggris siswa baik secara tunggal maupun bersama-sama. Korelasi positif mengindikasi bahwa peningkatan atau penurunan penguasaan kosakata dan minat siswa terhadap Bahasa Inggris cenderung diikuti oleh prestasi Bahasa Inggris siswa.
\end{abstract}

kata kunci: korelasi, minat siswa terhadap bahasa inggris, penguasaan kosakata, prestasi bahasa inggris siswa

\section{INTRODUCTION}

The role of English now in the development of many aspects in the world is undoubtedly very important. As a consequence, many Indonesians people attend to learn English offered by both government and private institution. In Indonesia, formerly English was taught to the students as a subject from the Elementary School to higher like Senior High School or University. "in education context, English has function as a means to communicate in the daily 
communication, to get knowledge, to make interpersonal communication, to share information and to enjoy language lesson in English culture. (Depdikbud, 2003: 6)

It is also expected to know how far the students master the given material and achieve the instructional objectives. It is also in English teaching and learning process. Test or evaluations are needed to measure how far the students master the material. In general, students will try to achieve success in learning English. According to Hornby (1987: 8), achievement is something done successfully, with effort and skill. While Brown (2004: 47) says that achievement test is related directly to classroom lessons, units, or even a total curriculum. From those experts, achievement is the one of the main part in learning process to know the effectiveness teaching process and the curriculum.

There are some factors that influence English achievement, Suryabrata (Endang Sri Markamah, 2002: 4) states that learning achievement is influenced by some factors, they are social factors (human), non-social (facilities), psychological (creativity, interest, progress), fisiology (physical). To get the high English achievement, students are demanded to have interest of English learning and master the vocabulary mastery too. The high English achievement is reflected in the high score. To get the high English score needs the high interest of learning and good vocabulary mastery too. Interest is a factor that influences English achievement. When students have self-awareness in English learning, they will be happy and interested to learn English subject, if they are happy and interested in it, they will study happily and get good achievement in English subject.

According to Nur Kholit Hazin (2004: 365) interest means attention, pleasure, and tendency. Slameto (Syaiful Bahri Djamarah, 191) defines interest is a preference and awareness to something or activity without any force. Interest is tendency of mood's someone to do something without forcing. Someone will be known his or her interest if there is tendency to be interested to an object whether he or she is happy or unhappy, so it results a respond to something which he or she likes. Interest is constant tendency to pay attention and do something. Activity which is interested by someone will be paid attention continually and happily. So, 
interest is different from attention, because attention is temporary (it is not for a long time) and it is not certain followed by pleasure, while interest is always followed by pleasure and there is satisfying.

Another thing that influences English achievement is vocabulary mastery. Vocabulary is one of the most obvious components of language and one of the first things applied linguists turned their attention to (Jack Richard, 2001: 4). According to Penny Ur (1998: 60) there are some elements that need to be taught in teaching vocabulary; they are form (pronunciation and spelling), grammar, collocation, aspect of meaning, word formation. Vocabulary is central of language in which it is the biggest component of any language and the success in learning language can be proved by the success in mastering vocabulary. It can be concluded that vocabulary mastery means complete knowledge or great skill of a list of English words that includes the meaning of words, spelling, pronunciation, and the use of words in right context.

Vocabulary is part of language element, so it is impossible to avoid vocabulary in using language for communication. Because of the importance of vocabulary in communication, now many experts have the same opinion as Nunan (1991: 118) said that these days, the consensus of opinion seems to be that the development of rich vocabulary is an important element in acquisition of a second language. Nation in Schmitt (1991: 6) states that vocabulary knowledge is only one component of language skills such as reading and speaking. It can be said that vocabulary is one of the elements in language. Among all the elements of language have interaction with others elements. Language knowledge well can be known from vocabulary used. Ur (1996: 60) defines vocabulary as the words we teach in the foreign language. Interpreting from Ur, vocabulary is a number of English word which is taught to students in teaching learning process. Related the learning process in school, vocabulary which is learnt should be appropriated with the curriculum. 
It is clear that vocabulary is important and needed for communication and needed in the acquisition of a second language, so it cannot be neglected in the teaching and learning language such as English and it must be taken into consideration in language learning achievement. Based on the theory about, the researcher wants to conduct research about correlation among them to know the achievement of learning English based English interest and vocabulary.

\section{RESEARCH METHODS}

Correlational method is a method whose goal is to describe the relation between two or more events or characteristics (Hallonen and Santrock, 1999: 20). While Allison (1996: 16) defines correlations are statistical relationships based on quantitative measures on two or more parameters. This research is one of quantitative research which measure on two or more variables. The reason of choosing this method is the researcher wants to know the level of correlation between two or more variables based on statistic quantitative in correlational coefficient.

There are two kinds of variable in this study, namely dependent variable and independent variable. The dependent variable in this study is English achievement $(\mathrm{Y})$, while the independent variables are vocabulary mastery $\left(\mathrm{X}_{1}\right)$ and English interest $\left(\mathrm{X}_{2}\right)$. It can be drawn there is a positive correlation between vocabulary mastery $\left(\mathrm{X}_{1}\right)$ and student's English achievement $(\mathrm{Y})$; there is a positive correlation between student's English interest $\left(\mathrm{X}_{2}\right)$ and student's English achievement (Y); and there is positive correlation between vocabulary mastery $\left(\mathrm{X}_{1}\right)$ and student's English interest $\left(\mathrm{X}_{2}\right)$ simultaneously student's English achievement (Y).

This research was carried out to the second semester Students of Islamic Education Department of Teacher Training and Education Faculty of IAIN Pontianak in the academic year of 2017/2018. The data are collected by using test, questionnaire, and documentation. The test are used to collect vocabulary mastery data (in the form of multiple choice test which consists of 30 items), while the questionnaire is used to collect the data of English interest (which consists of 40 items having four alternatives positive and negative items), and 
documentation is used to collect the English achievement data score taken from the teacher. In this study, the validity and the reliability of all items of each instrument above have been tried out. The validity test is using Product Moment Formula and the reliability test is using Kuder-Richardson for multiple choice instrument (the discrete score) and Alpha Croanbach for questionnaire instrument (continuum score).

The technique which is used to analyze the data was Linear Regression Analysis Statistic by using SPSS 23. The researcher tests the hypothesis using Product Moment and Multiple Linear Regression Formula. Product Moment Formula is used to describe the strength of relationship between two variables (single correlation), while Multiple Linear Regression is used to describe the strength between several independents variables and one dependent variable (multiple correlation). Before entering Linear Regression Analysis, there is major pre-requirement analysis for the data. They are normality test using Lilliefors formula, homogeneity test using Bartlett formula, linearity and significance using Anova test.

\section{RESULT AND DISCUSSION}

Based on the calculation of Lilliefors Significance Correction from Kolmogorov-Smirnov, it can be concluded that significance value of Vocabulary Mastery $\left(\mathrm{X}_{1}\right)$ is $0.394>0.05$; student's English Interest $\left(\mathrm{X}_{2}\right)$ is $0.064>0.05$; and student's English Achievement (Y) is $0.667>0.05$. So, from the result can be categorized that the data are in normal distribution.

The results of normality data can be described as follows:

Table 1. Table of One-Sample Kolmogorov-Smirnov Test

\begin{tabular}{llccc}
\hline \multicolumn{5}{c}{ One-Sample Kolmogorov-Smirnov Test } \\
\hline \multirow{2}{*}{$\mathrm{N}$} & & $\mathrm{X}_{1}$ & $\mathrm{X}_{2}$ & $\mathrm{Y}$ \\
\hline Normal Parameters ${ }^{\mathrm{a}, \mathrm{b}}$ & Mean & 50 & 50 & 50 \\
\cline { 2 - 5 } & Std. Deviation & 78.08 & 82.00 & 79.56 \\
\hline Most Extreme Differences & Absolute & 8.136 & 5.813 & 7.733 \\
\cline { 2 - 5 } & Positive & .127 & .185 & .103 \\
\hline
\end{tabular}




\begin{tabular}{lllll}
\hline & Negative & -.127 & -.140 & -.103 \\
\hline Kolmogorov-Smirnov Z & .899 & 1.311 & .726 \\
\hline Asymp. Sig. (2-tailed) & .394 & .064 & .667 \\
\hline a. Test distribution is Normal. & & & \\
\hline b. Calculated from data. & & \\
\hline \multicolumn{1}{l}{ The next step, based on the results below of Bartlett Formula, because }
\end{tabular}

Chi-Square value is lower than Chi-Square table, so it can be categorized that the variant data are homogeneous.

The results of homogeneity data can be described as follows:

Table 2. Table of Homogeneity Test

\begin{tabular}{|c|c|c|c|c|}
\hline \multirow[t]{2}{*}{ Variant } & \multirow[t]{2}{*}{$\mathrm{dk}$} & \multirow{2}{*}{$\begin{array}{l}\text { Value } \\
\chi^{2} \text { o }\end{array}$} & Table & \multirow[t]{2}{*}{ Result } \\
\hline & & & $\alpha=0.05$ & \\
\hline $\mathrm{Y}$ for $\mathrm{X}_{1}$ & 39 & 7.481 & 54.559 & Homogeneous \\
\hline $\mathrm{Y}$ for $\mathrm{X}_{2}$ & 36 & 3.246 & 50.964 & Homogeneous \\
\hline
\end{tabular}

The results of hypothesis testing

The first hypothesis finds that the computation of analysis regression $\mathrm{X}_{1}$ and $\mathrm{Y}$, it is found that coefficient $\mathrm{a}=30.219$, and $\mathrm{b}=0.632$, so equation regression is $\hat{\mathrm{Y}}=30.219+0.632 \mathrm{X}_{1}$. The significance of regression is found that $F_{o}=38.026$, and $F_{t}=4.04$ in the level of significance $\alpha=0.05$ and degree of freedom ( $d f=1: 48)$. Because $F_{0}>F_{t}$, so the regression of $X_{1}$ and $Y$ is significant. So, it can used to predict the correlation between vocabulary mastery $\left(\mathrm{X}_{1}\right)$ and English achievement (Y); it shows that the mean of English achievement (Y) would increase 0.632 if the vocabulary mastery $\left(\mathrm{X}_{1}\right)$ was increased one score in the constant score of 30.219 . The coefficient of correlation is $r_{x 1 y}=0.665$. Then, this value is compared to r-table at the significance level of $5 \%$ for $\mathrm{N}=50$, it is 0.279. The effective contribution of vocabulary mastery toward English achievement was $29.03 \%$, it means that $29.03 \%$ of English achievement is influenced by vocabulary mastery factor.

Coady and Huckin (1998: 5) state that vocabulary is central to language and critical importance to the typical language learner. Nunan (1998: 117) states that the acquisition of an adequate vocabulary is essential for successful second 
language use because without an extensive vocabulary we will be unable to use the structures and functions we may have learned for comprehensible communication. Because vocabulary is central of language in which it is the component of any language and the success in learning language can be proved by the success in mastering vocabulary. The analysis result above is there is a positive correlation between vocabulary mastery and English achievement. It means that the increase of student's vocabulary mastery is followed by the increase of student's English achievement.

The second hypothesis finds that the computation of analysis regression $\mathrm{X}_{2}$ and $\mathrm{Y}$, it is found that coefficient $\mathrm{a}=9.741$, and $\mathrm{b}=0.851$, so the equation regression is $\hat{\mathrm{Y}}=9.741+0.851 \mathrm{X}_{2}$. The significance of regression is found that $\mathrm{F}_{\mathrm{o}}$ $=33.314$, and $F_{t}=4.04$ in the level of significance $\alpha=0.05$ and degree of freedom $(\mathrm{df}=1: 48)$. Because $\mathrm{F}_{\mathrm{o}}>\mathrm{F}_{\mathrm{t}}$, so the regression of $\mathrm{X}_{2}$ and $\mathrm{Y}$ is significant. So, it can used to predict the correlation between English interest $\left(\mathrm{X}_{2}\right)$ and English achievement (Y); it shows that the mean of English achievement (Y) would increase 0.851 if the English interest $\left(\mathrm{X}_{2}\right)$ was increased one score in the constant score of 9.741. The coefficient of correlation is $r_{x 2 y}=0.640$. Then, this value is compared to $\mathrm{r}$-table at the significance level of $5 \%$ for $\mathrm{N}=50$, it is 0.279 . It means that $r_{x 2 y}$ is higher than $r_{t}$. It means that the correlation is significant; the effective contribution of English interest toward English achievement was $23.85 \%$, it means that $23.85 \%$ of English achievement is influenced by English interest factor.

Having pleasure feeling to English lesson motivate to do the positive attitude and finally it makes interest to English. Because of interest, students will be easier to understand English, so they will success in English learning. Suryabrata (in Markamah, 2002: 38) says activity which is followed by intensive attention will be more succeed, so the achievement is higher. It means because of interest to lesson which is learned, student will be happy and easy to do the task of the lesson. The analysis result above is there is a positive correlation between English interest and English achievement. It means that the increase of student's English interest is followed by the increase of student's English achievement. 
The third hypothesis finds that from the computation of multiple regression, it is found that the coefficient of $\mathrm{a}_{0}, \mathrm{a}_{1}$, and $\mathrm{a}_{2}$ are $6.519 ; 0.415$; and 0.496, so the multiple regression equation of $\mathrm{Y}$ on $\mathrm{X}_{1}$ and $\mathrm{X}_{2}$ becomes; $\hat{\mathrm{Y}}=6.519$ $+0.415 \mathrm{X}_{1}+0.496 \mathrm{X}_{2}$. The testing result of the significance of regression for $F_{o}$ is 26.367. This result is compared to F-table at the significance level of $5 \%$ and degree of freedom $(\mathrm{df}=2: 47)$ is 3.23. It means that $F_{o}(26.367)$ is higher than $\mathrm{F}_{\mathrm{t}(2,47)}$ (3.23), so $\mathrm{F}_{\mathrm{o}}$ is significant (table 7). So, it can used to predict the correlation between vocabulary mastery $\left(\mathrm{X}_{1}\right)$ and English interest $\left(\mathrm{X}_{2}\right)$ and English achievement ( $\mathrm{Y}$ ); it means that in every one score increase from vocabulary mastery $\left(\mathrm{X}_{1}\right)$ together with English interest $\left(\mathrm{X}_{2}\right)$ it increases 0.911 of English achievement $(\mathrm{Y})$ in the constant score of 6.519 , if there was no increase of vocabulary mastery $\left(\mathrm{X}_{1}=0\right)$ and there was no increase of English interest $\left(\mathrm{X}_{2}=\right.$ 0 ), it means every student has the mean of English achievement (Y) 6.519, it is shown by constant positive value, and it is 6.519 . The coefficient of correlation $\left(\mathrm{R}_{\mathrm{y} 12}\right)$ is 0.727 and $\left(\mathrm{R}^{2}\right)$ is 0.5287 . The effective contribution is $52.88 \%$, it shows that vocabulary mastery and English interest are some factors that influence English achievement. It means $52.88 \%$ factors that influence English achievement are come from vocabulary mastery and English interest factors, then $47.12 \%$ the rest was determined by other factors.

According to Hornby (1987: 8), achievement is something done successfully, with effort and skill. Suryabrata (Endang Sri Markamah, 2002: 4) states that learning achievement is influenced by some factors, they are social factors (human), non-social (facilities), psychological (creativity, interest, progress), fisiology (physical). One of the factors that influence student's achievement is interest, if someone is not interested to study something, he or she will not be hoped that he or she gets success well. But, the other way, if someone is interested to study something, so his or her achievement will be better. And in English, vocabulary is one of the points that must be mastered. Coady and Huckin (1998: 5) state that vocabulary is central to language and critical importance to the typical language learner. So, vocabulary and interest are important factors in achieving English. And the result is there is positive correlation between 
vocabulary mastery $\left(\mathrm{X}_{1}\right)$ and English interest $\left(\mathrm{X}_{2}\right)$ simultaneously English achievement (Y).

\section{CONCLUSION}

From the study, it can be concluded that there is a positive correlation between vocabulary mastery and student's English interest toward student's English achievement, both partially and simultaneously when in every one score increase from vocabulary mastery $\left(\mathrm{X}_{1}\right)$ together with English interest $\left(\mathrm{X}_{2}\right)$ it increases 0.911 of English achievement (Y) in the constant score of 6.519, if there was no increase of vocabulary mastery $\left(\mathrm{X}_{1}=0\right)$ and there was no increase of English interest $\left(\mathrm{X}_{2}=0\right)$, it means every student has the mean of English achievement (Y) 6.519, it is shown by constant positive value, and it is 6.519. It means that improvement of vocabulary mastery and English interest will be followed by the improvement of student's English achievement. It also means that student's vocabulary mastery and English interest contribute to their English achievement; with the effective contribution $52.88 \%$ in which $29.03 \%$ from vocabulary mastery and $23.85 \%$ from English interest.

\section{BIBLIOGRAPHY}

Allison, B. (1996). Research Skills for Students. London: Kogan Page

Brown, D. (2004). Language Assesment: Principles and Classroom Practice. San Fransisco State: Longman

Coady, J., \& Huckin. (1998). Second Language Acquisition: a Rationale for Pedagody. New York: Cambridge University Press

Djamarah, Syaiful, B. Psikologi Belajar. $2^{\text {nd }}$ edition. Yogyakarta: Aneka Citra

Hallonen, Jane S., \& Santrock, J, W. (1999). Psychology: Applied and Application, $3^{\text {rd }}$. Boston: McGraw-Hill College

Hornby, A. S. (2003). Oxford Advanced Learner's Dictionary of Current English. Oxford: University Press

Markamah, E, S. (2002). Prestasi Belajar Bahasa Inggris ditinjau dari minat belajar dan penguasaan kosakata siswa SLTP Negeri 3 Boyolali (Thesis). 
Surakarta: Program Studi Linguistik Program Pasca Sarjana Universitas Sebelas Maret

Nunan, D. (1991). Language Teaching Methodology. London: Prentice Hall

Nunan, D. (1998). Language Teaching Methodology: A Textbook for Teachers. New York: Prentice Hall

Nur, K, H. (2004). Kamus Lengkap Bahasa Indonesia. Surabaya: Terbit Terang

Richards, Jack C. (2001). Curriculum Development in Language Teaching. Cambridge: Cambridge University Press

Ur, P. (1998). A Course in Language Teaching. Cambridge: Cambrigde University Press 